\title{
Islam and the legal enforcement of morality
}

\author{
Christian Joppke
}

Published online: 9 October 2014

(C) Springer Science+Business Media Dordrecht 2014

\begin{abstract}
Over 60 years ago, British high court judge Patrick Devlin and legal philosopher H.L.A. Hart fought out a famous debate over the legal enforcement of morality, which was generated by the question of whether homosexuality should be legalized or not. Jurists agree that this debate was won by Hart, also evidenced in the fact that the state has since been retreating from its previous role of moral watchdog. I argue in this article that the two most conflicted and essentially unresolved issues in the integration of Islam, the regulation of the female body and of free speech, have reopened this debate anew, pushing the liberal state toward the legal regulation of morality, thus potentially putting at risk its liberalness. I use the Hart-Devlin debate as a template for comparing and contrasting the Muslim quest for restricting free speech with the host-society quest for restricting the Islamic veil. Accordingly, there is a double threat to liberalism, which this paper brings into view in tandem, one originating from Islam and another from a hypertrophied defense of liberalism.
\end{abstract}

Keywords Liberalism · Law $\cdot$ Regulation of morality · Islam · Free speech · Veiling

Over 60 years ago, British high court justice Lord Patrick Devlin and Oxford legal philosopher H.L.A. Hart fought out one of the twentieth century's most famous legal debates, which was over the question whether it is the business of the state to regulate morality by the means that are germane to it, law and ultimately force. This debate was kicked off by the recommendation of the so-called Wolfenden Committee to decriminalize homosexuality under English law. As the committee summarized its view: "It is not, in our view, the function of the law to intervene in the private lives of citizens, or to seek to enforce any particular pattern of behavior" (Wolfenden 1957, p. 10). Patrick Devlin rebutted that "there is such a thing as public morality," and that "society" had to "use the law to enforce its moral judgments" (Devlin 1965, p. 11). And the debate was on. Herbert Hart jumped to the rescue of the Wolfenden Committee with a restatement of John Stuart Mill's Harm Principle, according to which the "only purpose" for which liberal state power could be used against an individual's will is to

C. Joppke $(\bowtie)$

Institute of Sociology, University of Bern, Fabrikstrasse 8, 3012 Bern, Switzerland

e-mail: joppke@soz.unibe.ch 
"prevent harm to others" (Mill quoted in Hart 1963, p. 4). The Harm Principle, it should be said, is "accepted as valid by nearly all writers" today (Feinberg 1988, p. ix). Controversy exists, however, with respect to the question whether it is "the only liberty-limiting principle," as claimed by Mill (ibid.). Devlin's challenge was to posit a non-liberal "legal moralism" (Feinberg, ibid.) in addition to the liberal Harm Principle. According to legal moralism, the state could rightly restrict also "inherently immoral conduct," even though no one was harmed or offended by it (ibid.).

Undoubtedly, Hart has "won" this debate, first, in the opinion of jurists (Bassham 2012, p. 130). Joel Feinberg confirmed in an imposing four-volume treatise, The Moral Limits of the Criminal Law, that there is "no salvaging" of Devlin's "social disintegration thesis," according to which society would quite literally fall apart if its public morality was not policed by the state (1988, p. 145) (more on this below). But Hart won also matter-offact. This is demonstrated by the eventual (not immediate) ${ }^{1}$ legalization of homosexuality, a general retreat of the state from its previous role of moral watchdog and adoption of a neutrality stance, and the fact that greatly increased moral pluralism over the past half century has not led to the collapse of society, as Devlin would have predicted. With respect to the specific "morality policy" (Knill 2013) that sparked the Hart-Devlin debate, the restriction of homosexuality, Frank and McEneaney (1999) found that, from the mid1980s to the mid-1990s alone, of 86 examined countries 24 changed their same-sex policies, and "nearly every change was one toward liberalization" (p. 912). Frank and collaborators ground this liberalization in a world-wide process of "individualization," according to which persons are "disembedded" from corporate entities like family or nation and "re-rendered ... as autonomous, empowered actors" (Frank et al. 2010, p. 887). This has transformed the function of the law. Importantly, the state "did not 'get out of the bedroom"' (ibid., p. 877), but merely shifted focus from protecting "corporate bodies" to protecting "persons." Accordingly, Frank et al.'s study of "sex laws" in 194 countries over a 60-year period (1945-2005) found that a "contraction" in laws against adultery and sodomy, which had preserved "collective entities" like family, nation or religion for their own sake, was counterpoised by an "expansion" of laws against rape and child sexual abuse, which ignored collective concerns and preserved "individual entities" instead, and which were based on the consent principle: "We suggest that the rise of the individual between 1945 and 2005 raised the priority of individual consent and lowered the priority of collective order across the policy field" (ibid., p. 887).

In a side note, Frank et al. report "outright resistance" to the observed global trend in a "few fundamentalist Muslim countries" (2010, p. 887), but don't further explore the anomaly. I argue in this article, though with a focus on Western societies, that the integration of Islam has raised the issue of moral regulation by law anew. Concretely, the two persistently conflicted and essentially unresolved issues in the integration of Islam in Western societies, which are the regulation of the female body for the sake of liberal values and the restriction of free speech for the protection of religion, are pushing the liberal state toward the regulation of morality, at the price of restricting individual liberties and putting at risk the liberalness that it has hard-won over the past half century (see also McLeod 2010, ch.10).

Juxtaposing these two critical issues in Islam integration shows something interesting: the quest for moral regulation originates here from opposite quarters, Muslim and host-

${ }^{1}$ Homosexuality was legalized in Britain only in 1967, a decade after the Wolfenden Committee recommendation. 
society claimants. Prohibitions of Islamic veiling, which are justified for the defense of secular and liberal values, originate from host-society actors. By contrast, the quest to restrict free speech to protect religion originates from Muslim actors. This implies different chances of success for both morality campaigns: restrictions of veiling have overall been more successful than restrictions of free speech. But one should not define success too narrowly, in terms of the presence or absence of legal regulation. Restrictions of veiling, while often legally successful, have everywhere been controversial, stirring vehement public debate over the limits of liberal state intervention, and exposing the one Western country that has gone furthest with this: France, to international criticism if not ridicule. On the other side, the curtailing of free speech for the sake of Islamic piety may have been legally unsuccessful, but Western state and cultural elites have still set the standard of "insensitive" expression in this area suspiciously low. Note that the Western world's most mediatized elder statesman, former US president Bill Clinton, denounced the so-called Danish Cartoons (that had depicted the Prophet in a satirical way and stirred world-wide conflict) as "appalling," fathoming that "anti-Islamic prejudice" had taken the place of the "anti-Semitic prejudice" of the past (in Bleich 2011, p. 3). Britain's major newspapers refused to reprint the incriminated cartoons, which amounted to indirect censorship. In the United States, a major university press removed the cartoons from a social science book that, ironically, covered the very controversy stirred by them (Klausen 2009). While free speech law was not changed anywhere, the sympathy for the Muslim outrage expressed by political and media elites must still count as a considerable "success" of the international Muslim campaign.

In the following, I use the Hart-Devlin debate as a template for comparing and contrasting the Muslim quest for restricting free speech with the host-society quest for restricting the Islamic veil. I argue that both attempted restrictions rest on misleading notions of what a society is (as integrated by a public morality) and of what the proper function of the law in a liberal society is (which is to protect individuals not corporate entities or God). In a nutshell, both morality campaigns run afoul of arguments that H.L.A. Hart had convincingly brought against Justice Devlin.

In a first step, I rehearse the central arguments in the Hart-Devlin debate. Secondly, I use the terms of this debate, particularly Hart's timelessly and continuously acute liberal position, as a template and benchmark to compare and contrast the veiling and free speech restriction quests in the context of Islam integration. In the conclusion, I discuss three possible objections to applying the terms of the Hart-Devlin debate to the issue of Islam integration, and I briefly touch on the prickly but unavoidable question whether there are specific difficulties of integrating Islam into liberal and secular societies.

The mixing of normative legal argument and empirical case study, as tried in the following, is unusual for a sociology article. Sociology, much more than political science, thrives on the fact-value distinction as canonized by Max Weber, and it generally abstains from normative argument. While there is normative political theory, "normative social theory" is yet to be invented. ${ }^{2}$ Accordingly, an orthodox sociological approach would be to take normative arguments as claims raised by actors, and then

\footnotetext{
${ }^{2}$ Of course, there is Critical Theory in the Marxist tradition, most imposingly Jürgen Habermas's theory of communicative action, the radical critique of power by Michel Foucault, and too many other normative approaches to mention. But they do not add up to "normative social theory" comparable to "normative political theory," which is more encompassing and established though, of course, divided in many approaches and traditions, "liberal," "communitarian," "radical," etc.
} 
explore repertoires of justification, discursive constructions of "problems" to be resolved by state policy, and evolving actor constellations (e.g., Gusfield 1968). ${ }^{3}$ However learned and interesting it might be, the Hart-Devlin debate yields nothing in this respect. However, what one can learn from this debate is a sharpened sense for the limitations of liberal law, and a correction to flawed views about what "integrates" society, particularly the role of "values" and "morality" in this. These are central themes of sociology since Durkheim. More importantly still, these are themes of considerable practical import, as in the current political debate over "integrating" Islam and Muslim immigrants into liberal societies. It is useful and value-adding to see these themes refracted through the prism of another discipline, in this case jurisprudence. With few exceptions (notably, Starr 2007) sociology as a discipline has stood aloof of the great debate over the future of liberalism. It does so at its own peril.

\section{The Hart-Devlin debate}

Devlin's intervention, in his famous Maccabean Lecture in Jurisprudence read at the British Academy in 1958, was not so much directed against the substantive conclusion of the Wolfenden Committee, which was to decriminalize homosexual acts between consenting adults. Not hiding his personal disapproval of these practices, he still concedes (in language that would not be considered fit for print today): "I was in favour of reform.... I do not think that there is any good the law can do that outweighs the misery that exposure and imprisonment causes to addicts who cannot find satisfaction in any other way of life. Punishment will not cure and because it is haphazard in its incidence I doubt if it deters" (Devlin 1965, p. v). Accordingly, rather than oppose the liberal recommendations of the Wolfenden Committee, Devlin found fault with the liberal view of the law expressed in them. His reasoning consisted of three elements.

First, there is a view of what society is, and what role the law plays in keeping it together. Society is constituted by a "public morality," the "invisible bonds of common thought" (Devlin 1965, p. 10). And the function of the law, in particular criminal law, is the protection of society and thus of the morality that is said to be constitutive of it. His main proof is that the "consent of the victim" is no reason to stop a criminal law procedure. Punishment must thus be revenge for an "offense against society," the latter standing above individuals as a corporate entity; punishment is the warding off of a threat to "one of the great moral principles upon which society is based, that is, the sanctity of human life" (ibid., p. 6).

Devlin's squaring of social integration with criminal law is deeply reminiscent of Durkheim's Division of Labor in Society (1984 [1893]), as noted by Hart (1967, p. 6), with one important difference. For Durkheim, criminal law was expressive of only one type of social integration, which he called "mechanical solidarity," and which he deemed predominant in traditional peasant societies. But he saw it trumped in modern industrial societies by a more contractual type of integration, which he called "organic solidarity," and which he deemed expressed not in criminal but in civil law. Accordingly, to answer the question what integrates modern society, Durkheim would look for sources other than "public morality" (in his words: conscience collective), the

\footnotetext{
$\overline{3}$ This point was raised by a perceptive anonymous reviewer of this article.
} 
latter being more the way traditional society was kept together (essentially through religion). In fact, for the integration of modern society Durkheim would home in on the "cult of the individual," or the "individualization" that Frank et al. (2010) deemed responsible for moving sex laws away from protecting corporate entities to protecting individuals.

Secondly, when fleshing out the function of the law to enforce society's "moral judgments" (Devlin 1965, p. 12), Devlin draws an analogy between "treason" and "immorality" as two equal-level, fundamental attacks on the very existence of society. But if there are "no theoretical limits" to the power of the state to legislate against treason, his analogy goes, "it is not possible to set theoretical limits to the power of the state to legislate against immorality" (ibid.). Similarly, argues Devlin, "You cannot set a theoretical limit to the number of people who can get drunk before society is entitled to legislate against drunkenness" (ibid., p. 14). However much the treason analogy "grates in the ears," as Eugene Rostow found it, not at all in disapproval (1960, p. 184), it seems logical: if you "cannot have a society without morality," the law can and must be used to "enforce morality as something that is essential to a society," to repeat, without any "theoretical limits" (Devlin 1965, p. 14).

Thirdly, to the question of how to ascertain what the "moral judgments of society" are, Devlin's answer is: "The man in the Clapham omnibus" (Devlin 1965, pp. 14-15). Or less colloquially speaking: "What the lawmaker has to ascertain is not the true belief but the common belief" (ibid., p. 94). This is a very British, common-law inspired solution to the question of public morality, which gives more to the "power of a common sense" than to the "power of reason" (ibid., p. 17). As Eugene Rostow observed, "In the life of the law, especially in a common law country, the customs, the common views, and the habitual patterns of the people's behaviour properly count for much" (1960, p. 197, emphasis supplied). But to "assume that the moral judgements made by a society always remain good for that society" (Devlin 1965, p. 18) still is a daring wager. As Joel Feinberg asks (1988, p. 138), only half-tongue-in-cheek: what about the $10 \%$ of Clapham omnibus riders who are likely to be practicing homosexuals themselves, following the estimation of the contemporaneous Kinsey Report? Of course, not any such "judgement" warrants the restriction of individual freedom. "Morality," argues Devlin, "is a sphere in which there is a public interest and a private interest, often in conflict, and the problem is to reconcile the two" (Devlin 1965, p. 16). The respect for "private interest" commands that "There must be toleration of the maximum individual freedom that is consistent with the integrity of society" (ibid., p. 16). Only if there is a "real feeling of reprobation," or as Hart put it with a sense of drama: only if "intolerance, indignation, and disgust" are at "concert pitch" (Hart 1959, p. 162), state intervention is warranted. But there is still no other basis for this reprobation than mere "feeling." One cannot avoid the conclusion that Devlin's amounts to a "totally irrationalist conception of morals" (Wollheim 1959, p. 39).

Each of Devlin's three assumptions has been subjected to a devastating critique by Hart (and others, including, at the time, Dworkin 1977 [1966] and Wollheim 1959; three decades later and most detailed, Feinberg 1988, ch.30). With respect to the first assumption, that society is "identical with its morality" (Hart 1963, p. 51), this would rule out the possibility of moral change. Instead, one would be forced to argue that in the case of moral change "one society (has) disappeared and another one taken its place" (ibid., p. 52) — which is patently absurd. As Hart objects to Devlin, the latter 
espouses a "confused definition of what a society is" (ibid., p. 82), as something that is constituted by morality as a "seamless web," the attack on one bit of which would bring the whole structure down.

Devlin answered Hart's critique in a lengthy footnote (1965, p. 13, fn. 1). Not "any" deviation from a "society's shared morality threatens its existence"-rather, this was a matter of degree. Further, he likens the relationship between society and morality to that between a "game" and its "rules." Hence, there is a certain "identity" between both, but it is again a matter of degree: "If I am asked whether a change in the rules means that one game has disappeared and another has taken its place, I would reply probably not, but that it would depend on the extent of the change" (ibid.). Overall, Devlin describes the simple thrust of his proposition as follows: "(I)f you cannot have a society without morality, the law can be used to enforce morality as something that is essential to a society" (ibid., p. 14).

But even in this softened version, the purpose of the law was still not primarily to prevent harm or suffering, as it is within the ambit of Millian liberalism, but to protect morality, as something that stands above and prior to individuals and that is transcendent to them like once religion was. Accordingly, Hart finds this communitarian view, as we would call it today, "uncomfortably close" to endorsing "human sacrifice as an expression of religious worship" (1963, p. 66). The mistake seems to be, points out Richard Wollheim (1959), to ground the unity of society not in shared "political" but narrowly "moral" or ethical ideas, untainted by the "forum of discussion." This undercuts liberalism, which builds the "identity" and "continuity" of a society "not in the common possession of a single morality but in the mutual toleration of different moralities," as Wollheim put it, decades before "political liberalism" would provide the same solution (p. 38).

There was indeed something paradoxical about Devlin's conception of morality. On one side, he ascribed to it "an objectivity that goes far beyond ordinary demands"; on the other side, he grounded it "in total subjectivity" (Wollheim 1959, p. 39). As it were, Devlin conceived of morality simultaneously as "religion" and "feeling," whereby an attack on morality came to be primarily addressed in terms of the "social harm" generated by it. In Feinberg's terms, Devlin was an "impure" moralist, whose position was imbibed with elements of the liberal harm principle (1988, p. 139). With respect to the morality-religion relationship, Devlin thought that "morals and religion are inextricably joined," both having Christian roots, at least in our "Western civilization" (1965, p. 5). He even claims that "A State which refuses to enforce Christian beliefs has lost the right to enforce Christian morals" (ibid.). This plainly places Devlin outside the ambit of liberalism, in fact closer to liberalism's "rivals" like Catholicism or Communism that subordinate the individual to a hypostasized truth doctrine and collectivity in which the doctrine reigns (Wollheim 1959, p. 38).

No wonder that Devlin shrinks back from the illiberal consequences of his own position, suddenly arguing that "the secular law must be made for unbelievers since it does not require religious belief as a condition of citizenship and exacts compliance from the religious and the irreligious" (Devlin 1965, p. 63). Only, this liberal concession sits uneasily with the quite opposite claim that "No society has yet solved the problem of how to teach morality without religion" (ibid., p. 25). In the end, Devlin's position boils down to the rule of the religious over the unreligious, a theocracy of sorts tempered by British pragmatism. 
With respect to Devlin's second assumption, the analogy of "immorality" and "treason," on which he grounds a potentially unlimited level of state intervention in the regulation of morality, it is not difficult to find it logically flawed. While there can be private immorality, notably in matters of sexual practice, there cannot be "private treason": "private subversive activity is, of course, a contradiction in terms" (Hart 1959, p. 163). Treason is intrinsically public. By contrast, immorality can be private, in fact it most often is private, as in sexual matters, and thus it cannot be as big a threat to society as treason.

The distinction between private and public morality is one of the fuzziest and most danced around in the Hart-Devlin debate. Devlin seems to deny a clear-cut distinction between both. And we have to follow him, to a degree, if we want to get mileage out of this debate for the integration of Islam, which is clearly a public, not private morality issue. ${ }^{4}$ Hart, in turn, as in his rejection of the "treason analogy," seems to give much to the private vs. public morality distinction. So did the Wolfenden Committee itself. To quote the central passage of its 1957 report at length:

(The) function (of the criminal law), as we see it, is to preserve public order and decency, to protect the citizen from what is offensive or injurious, and to provide sufficient safeguards against exploitation and corruption of others, particularly those who are specially vulnerable because they are young, weak in body or mind, inexperienced, or in a state of special physical, official or economic dependence.... It is not, in our view, the function of the law to intervene in the private lives of citizens, or to seek to enforce any particular behavior, further than is necessary to carry out the purposes we have outlined (Wolfenden 1957, pp. 9-10).

This statement is significant in several respects. First, only "criminal law" is mentioned, which is logical given the subject of the inquiry - the question whether homosexuality should continue to be considered a "crime." However, it is not difficult to extrapolate from it a view of the function of the law in general in a liberal society, one that squares largely with Mill's Harm Principle and the protection of individual liberty. The only seeming exception is the law's function of "preserv(ing) public order and decency." However, the context leaves no doubt that "public order" and "decency" would have to be interpreted in a way commensurable with the harm principle, as condition and expression of it, respectively. Hart at least interpreted "decency" in this way: if bigamy and blasphemy are still punished today, it is not for their violation of an objective "morality" standing above human interest but for their violation of subjective "decency"- the "offence to feelings" is key (Hart 1963, p. 43). In Feinberg's (1985) terms, reconstructed blasphemy laws, for instance, could be interpreted as warding off "offense" as a lesser kind of violation of another person's interest or integrity (if compared with "harm"), examples being "shock, disgust, or revulsion." However, only "profound offenses," according to Feinberg, are justifiable grounds of a criminal law intervention from a liberal point of view (that is defended by him as it was defended earlier by Hart).

\footnotetext{
${ }^{4}$ When I presented the idea for this article in Jerusalem, Ruth Gavison (Hebrew University) denied the applicability of the Hart-Devlin debate to the Islam issue, arguing that the former was about "private" whereas the latter was about "public" morality, the need for "shared values" in society. I further address this objection in the conclusion.
} 
But for our purposes the key phrase in the central passage of the Wolfenden Committee report is that the law should "not ... intervene in the private lives of citizens" (Wolfenden 1957, p. 10), unless the inherently subjective, individualcentered values enumerated there stand to be protected. This key point was even more crisply articulated in Section 61 of the same report: "Unless a deliberate attempt is to be made by society, acting through the agency of the law, to equate the sphere of crime with that of $\sin$, there must remain a realm of private morality and immorality which is, in brief and crude terms, not the law's business" (Wolfenden 1957, p. 24). Even Devlin, despite his strong views on the religious bases of morality, was "against the equating of crime with sin" (1965, p. 4). But then a private-public distinction in matters of morality was difficult to reject, and it is this point that the Wolfenden Committee and Hart picked up and got them running.

The immunization of a private sphere of morality unreachable by the state was still attacked by Devlin. Although he nowhere says it directly, Devlin seems to deny the possibility of a purely private morality (or immorality), without import for other people or society. This is because morality, however internalized and made the individual's own light, always consists of rules of how to live in common. Consider the Golden Rule, the kernel of all morality, variants of which are known to all world religions and the civilizations that sprang from them. Its content is not to inflict on others what one would not want to have inflicted on oneself. A private Golden Rule is impossible; this core of all morality is an inherently social and thus public thing. In this respect, Devlin's tying of a punishment under criminal law to a "public morality," which cannot be undone by the "consent" of the victim but stands to be retained for its own sake, has an irrefutably strong point (p. 6) — even Devlin's unsparingly liberal critic Feinberg (1988, p. 174) concedes that in this one respect Devlin is "at his most impressive."

Despite a partial scoring on the private v. public morality issue, the potentially illiberal consequences of Devlin's position are blatantly visible in his third assumption, which is to make the "man in the Clapham omnibus" the arbiter of morality. As Hart retorted to this assumption, it provides no argument against "the burning of old women for witchcraft," or "Apartheid," or any other practice that may have been required for the sake of public morality in less liberal times and places: "Morality, what crimes may be committed in thy name!" exclaims Hart (1959, p. 163). Unless a distinction is made between "positive" and "critical morality," says Hart (1963, p. 20), the first being the morality "actually accepted and shared" in a society and the second being the "general moral principles used in the criticism of actual social institutions," the consequence would be "moral populism." This is another word for Mill and Tocqueville's "Tyranny of the Majority," that is, the "view that the majority have a moral right to dictate how all should live" (ibid., p. 79), which both classical liberal thinkers identified as the intrinsic risk of democracy.

The distinction between "positive" and "critical morality" is astonishing coming from H.L.A. Hart, as it is as a legal positivist that he has become a household name. But it is the necessary conclusion to draw when the idea is to be resisted that the "man on the Clapham omnibus" could tell us how to live. The point was picked up with acumen by Ronald Dworkin, who argued that to make "feeling," unfettered by "reason" the benchmark of morality does not allow distinguishing it from mere "prejudice" or "personal taste." A genuinely "moral position" requires "reasons" to be given. "What is shocking and wrong," argues Dworkin, "is not (Devlin's) idea that the community's 
morality counts, but his idea of what counts as the community's morality" (1977, p. 255). This, incidentally, exposed Dworkin as yet another "legal moralist," only one in rationalist, not empiricist, garb (Feinberg 1988, p. 142f).

Hart's acidic disassembling of Devlin's case for legislating morality throws a critical light on an entire sociological tradition that, from Durkheim to Parsons, has stipulated the centrality of "common values" for societal integration - a view, of course, that has long been discredited within the discipline itself (one of the most trenchant critiques remains Mann 1970). And it has to be conceded that the sociological description of (the need for) common-value integration is one thing, while the legal scholar's normative carving out the limits of liberal state intervention is quite another thing. In fact, not so much sociology as the practical world of politics is the pertinent contemporary address for Hart's Devlin critique. Note, particularly in Europe, the new "civic integration" policies that busily try to instill, by way of law and public policy, "common values" on their immigrant populations, especially those of Islamic origins (for an early account, see Joppke 2007a; more recently, Wallace Goodman 2012). From a Hartian point of view, civic integration (at least the harsher versions of it) amount(s) to a legal enforcement of morality that may pose a bigger threat to liberal democracy than Islam or Muslims could ever be.

\section{Enter Islam}

Let us therefore move to the two critical issues in Islam integration that have raised the problem of legislating morality anew. From the Rushdie Affair of 1989 to the Danish Cartoon Controversy in 2005 (Parekh 1990; Klausen 2009), and from the French Foulard Affair in 1989 to the French burka law passed in 2010 (Bowen 2006; Scott 2007; Joppke 2009a, ch. 2; Joppke and Torpey 2013, ch. 2), one notices that it is always the same two issues that are particularly intense, periodically renewed, and essentially unresolved. These two issues are the regulation of free speech, on the one hand, and of the female body, on the other. They actually deflect from an otherwise successful, though mostly silent and piecemeal process of integrating Islam by law (see Dassetto et al. 2007; Joppke and Torpey 2013; most recently Hafez 2013, ch. 1).

\section{Free speech and blasphemy}

Let us start with the Muslim quest to restrict free speech, for the sake of protecting the integrity of their religion or of their group, which in effect amounts to the same. ${ }^{5}$ Of course, Western state law, sometimes to the present day, has sanctioned "blasphemy." But such laws have fallen dormant (as in Britain until the conflict surrounding Rushdie's

\footnotetext{
5 In principle, there is a distinction between protecting "religion" and the "group" assembled by it. When "blasphemy" first became a common law offense in seventeenth century England (previously it had been adjudicated within the Church's Canon Law), there was certainly no element in it to protect Christians as a "group". This is because English (and European) society was thoroughly Christian, but more importantly because at the time "God" not "people" stood to be protected. In today's pluralistic societies, religious belief immediately flags group membership, particularly for Islam as a minority religion in Christian majority societies. In addition, the "groupist" tilt of extant blasphemy laws is due to their human-rights-era refashioning as warding off "offense" to the "feelings" of religious believers (see below). Still, even within reconstructed blasphemy laws there is the possibility to protect the integrity of groups or of individuals. For an instructive comparison of England (protecting groups) and the United States (protecting individuals), see Post (1988, pp. 305-324).
} 
incriminated Satanic Verses), or they have been abolished (in Britain in 2008, as a late effect of this controversy). Where blasphemy laws still exist, they protect all religions (as in Ireland), or even non-religion (as in Germany and Austria), and they are construed to protect the "social peace" as "precondition for the preservation of all other rights" (Hafez 2013, p. 35). This notionally folds back the remaining blasphemy laws to the parameters of liberal law. Indeed, when Britain finally abolished its three-centuries-old blasphemy law, to deflect a long-standing and unavoidable Muslim quest to be included, the extant blasphemy prohibition no longer protected religious truth, as initially, but the religious feelings of believers, and thus was assimilated to the religious liberty protections of a liberal state (see Jones 1980, 1990).

Still, even in the context of reformed blasphemy laws it is not clear why religious feelings (and not political and other ethical feelings) should enjoy special protectiontherefore the inclusion of non-religious worldviews (Weltanschauungen) as protected under Article 166 of the German penal code (Hafez 2013, p. 35). Secondly, a legally ordered "respect for beliefs" (Jones 1990, p. 416) threatens to destroy the meaning of free speech protection, which is necessary exactly when an opinion hurts and is meant to hurt. Defending his Satanic Verses, Salman Rushdie has expressed the function of free speech protection well: "What is freedom of expression? Without the freedom to offend, it ceases to exist. Without the freedom to challenge, even to satirise all orthodoxies, including religious orthodoxies, it ceases to exist. Language and the imagination cannot be imprisoned, or art dies, and with it, a little of what makes us human" (quoted in Parekh 1990, p. 706).

The Islamic religion does not know the exact concept of "blasphemy"; but all of its variants prohibit the turning away from Islam in unbelief or for another belief (riddah). According to classic sharia law, riddah is punishable by death (see Parekh 1990, p. 698; also Asad 2012, p. 288). At international level, the Organization of Islamic States (OIS) has long campaigned for classifying the "defamation of religion" as analogous to a human rights violation. This amounts to smuggling in an alien (because non-individual centered) element into human rights law. Strongly rejected by Western states, this campaign has been partially successful at global level, as demonstrated by UN General Assembly Resolution 62/154 of 18 December 2007, entitled "Combatting Defamation of Religions." It calls upon the Secretary-General of the United Nations Organization (UNO) to examine the "possible correlation between defamation of religions and the upsurge in incitement, intolerance and hatred in many parts of the world" (UN General Assembly 2008, p. 4). Supported by all Middle Eastern states (except Israel), the great majority of states from Asia (including Russia and China), Africa, and South America, and in turn rejected by all EU states, the Antipodes, Canada, and the US (see Ali Khan 2007, p. 2), this UN General Assembly resolution raises several thorny issues:

- first and most importantly for our purposes, to extend defamation from persons to ideas or God;

- secondly, to equate race and religion;

- thirdly, to lower the threshold of offense from "intent" to the mere "feeling" of being offended, if not the circumstance that violence happened to be the response by the offended party, which is thus indirectly justified;

- fourthly, and empirically most worrisome, to provide a cover for discriminatory blasphemy laws in Muslim-majority societies. 
With respect to the first problem, the outlawing of "defamation of religion" would grant rights protection not to human beings but to religious doctrine or even God himself, who-weirdly to the liberal eye - in Islamic understanding is the only entity endowed with rights. The Iraqi intellectual and homme politique, Ali Allawi (2009, p. 11, and ch. 8), noted that the "whole system of individual rights is foreign to the structure of Islamic thinking." Traditionally, the legal notion of "defamation" applies only to violations of the reputation of individuals. Already the extension to "group" is problematic, as it may "stifle free speech" and provide "undeserved protection" to repressive customs and practices (Ali Khan 2007, p. 3). Extending it even further, to "religion," would make "religious ideas and doctrines" (ibid.) the subject of protection. This is why General Assembly (GA) Resolution 62/154, which mentions only Islam in name and has in fact been introduced by Muslim countries, has been rejected by all Western states as "direct violation" of international human rights law (ECLJ 2008, p. 1).

Secondly, to make the "defamation of religion" compatible with human rights law, the OIC strategy has been to equate it with "racism against Muslims" (ECLJ 2008, p. 6). Of course, the entire campaign for recognizing "Islamophobia" as analogous to antiSemitism and racial discrimination rests on this strategy. In their opposition to GA Resolution 62/154, the EU states objected to this that "members of religious or belief communities should not be viewed as parts of homogenous entities" (quoted in ibid.); even the UN Special Rapporteur on Racism cautioned "against confusion between a racist statement and an act of defamation of religion" (quoted in ibid.). At a minimum, race is "immutable" while religion involves the "freedom to follow one's conscience" (Becket Fund 2008, p. 5). It is a valid claim that the freedom of conscience, which is experienced by the true believer as non-optional, a "dictate," is not to be equated with the freedom of choice (see Sandel 1998, pp. 86-87). But to equate religious with racial discrimination is still problematic, because it "confuses racist hate speech with discussion of (sometimes controversial) truth claims" (Becket Fund 2008, p. 5).

Thirdly, critics of the "defamation of religion" resolution have pointed out that it replaces the focus of existing law on the "intent" to incite hatred or violence against religious believers with a rather capricious focus on whether "believers feel offended by the speech" (ECLJ 2008, p. 1). At times even the "dubious claim" was raised that speech may be problematic not through inciting violence "towards" a targeted group but because violence has resulted "from" the targeted group (ibid., p. 7)-which is formally equivalent to the noxious claim that a rape is "invited" by the victim.

Fourthly, the OIC campaign for outlawing the "defamation of religion" has provided a cover for harsh and actively implemented blasphemy laws that are long in place in most Muslim states, and which are selectively used against Christian and inner-Islamic minorities. In Pakistan, which has been the driving force behind UN General Assembly Resolution 62/154, blasphemy is punished by death, but naturally only if the Islamic

\footnotetext{
${ }^{6}$ The European Center for Law and Justice (ECLJ), based in Strasbourg, it should be said, is no neutral or ordinary human rights observer, particularly not on religious issues, as it is funded by right-wing Evangelists in the United States. I make use of only one of its reports (ECLJ 2008). Submitted to the UN High Commissioner on Human Rights, this is a rare (and critical) account of the OIC religious defamation campaign, and mostly does not seem to be tainted by the organization's evangelist background. I crosschecked its mentioned findings or statements as much as possible with other sources.

${ }^{7}$ During the second Iraq war, British Muslim organizations have attacked British military involvement with the exact same argument, that it has triggered violence on the part of some Muslims (see Joppke 2009b).
} 
God is involved. Since the Pakistani Penal Code 295, which outlaws blasphemy, was introduced in 1986, around 900 individuals were charged under it. A US State Department report confirms that anti-blasphemy law in Pakistan is "often used to intimidate reform-minded Muslims, sectarian opponents, and religious minorities, or to settle personal scores" (Becket Fund 2008, p. 5). For an OIC representative, of course, the "defamation of religions" campaign is not to stifle the freedom of expression and "civilized criticism." Rather, "the target is to invite everybody to respect Islam." What the OIC representative does not mention is that this "invitation" serves in Islamic states mainly for the persecution of Christian and Islamic minorities (like the Ahmadis), and thus functions as "instrument of political and social coercion."

However much blasphemy laws, qua attacking "defamation," are assimilated to a liberal human rights framework, they still do not escape the stinging criticism raised by H.L.A. Hart against Patrick Devlin: "The idea that we may punish offenders against a moral code, not to prevent harm or suffering or even the repetition of the offence but simply as a means of venting or emphatically express moral condemnation, is uncomfortably close to human sacrifice as an expression of religious worship" (Hart 1963, p. 66).

The so-called Danish Cartoon Controversy, sparked by world-wide Muslim indignation against the reprinting of drawings depicting the Prophet Mohammad in a satirical way in a Danish newspaper, has been called "the first truly global crisis of the twenty-first century" (Laborde 2011, p. 603). Despite being cynically fabricated by a small Muslim leadership, it revealed deep frictions between a "liberal" and an "Islamic" view of law and society. In the sealed towers of American elite academia, these frictions pulse through an interesting exchange between Yale constitutional lawyer Robert Post, expressing a "liberal" view, and University of California Berkeley anthropologist Saba Mahmood, who takes an "Islamic" position. Post, a leading First Amendment ("free speech") scholar, argued that the cartoons, however much they may violate religious sentiments, could and should not be legally prohibited because the freedom of expression is necessary for the "value of democratic legitimation" (Post 2007 , p. 77). Interestingly, Post identifies in the "more normatively hegemonic" states of Europe a tradition of restricting the freedom of expression through "civility norms" that the American legal tradition, in the Constitution's First Amendment, abjures for the sake of absolutized free speech (for European civility norms, grounded in an aristocratic culture of "honor," see Whitman 2000). As example of such civility norms he cites the old blasphemy laws, which always "express the mores of dominant groups" (Post 2007, p. 82). To the degree that European states have reformed or even abolished such laws, as most of them did in recent years, they have moved closer to the American (or, rather, liberal) ideal of neutrality.

Such intra-Occidental niceties are glossed over in Saba Mahmood's (2007) broadside against Post (2007), which attacks the entire "secular liberal law" as "constitutively and normatively Judeo-Christian." In her view, Muslims never have the chance of "hearing their religious sensitivities fairly addressed," in America as little as in Europe (Mahmood 2007, p. 2). Post's "democratic norms" in reality equal the "supremacy of majoritarian norms in the interest of public order" (p. 3).

\footnotetext{
${ }^{8}$ The Economist, 3 April 2010, p. 55.

${ }^{9}$ A researcher at Human Rights Watch, quoted in "The limits of freedom and faith," The Economist, 3 April 2010, p. 55.
} 
But what are the "religious sensitivities" of Muslims that are flattened by Western "secularism"? In a discussion of the Danish Cartoon Controversy, Mahmood distinguishes between a "modern concept of religion" that sees religion "as a set of propositions in a set of beliefs to which the individual gives assent," and which is "Protestant," and an "Islamic" understanding of religion, where "signs" do not just "represent" something and are thus not exchangeable, and where there is no difference between symbol and reality (2009, p. 843). The Westerner is beholden to a "semiotic ideology" that stipulates certain "sets of distinctions": between object and subject, substance and meaning, signifiers and signified, form and essence. Muslims do not make these distinctions, argues Mahmood. Instead, "attachment and cohabitation" (p. 842), and "intimacy with the Prophet" (p. 846) are at the core of the Islamic understanding of religion. "A devout Muslim's relationship to Mohammad," says Mahmood (ibid., p. 847), "is predicated not so much on a communicative or representational model as an assimilative one. Mohammad is not simply a proper noun referring to a particular historical figure but marks a relation of similitude." Because Muslims cannot make a distinction between symbol and reality, it follows that what to a Westerner appears as innocuous (at worst tasteless) drawings inflicts on them "hurt, loss, and injury" (p. 846). More than constituting a "transgression of the law," the cartoons have "(shaken) a relationship of dependency with the Prophet" (848f). And, in turn, Muslims could never expect rescue by European hate speech law, nay, by "secular law" at large, because it "privilege(s) the cultural and religious beliefs of the majority population" (p. 857).

Following Klausen (2009), Laborde (2011, p. 603) reasonably discards a "simplistic" reading of the Danish Cartoon Controversy in terms of a "clash of civilizations." However, Mahmood's (impeccably "correct") version of the event does not seem to be so far from such reading. Mahmood (2009) may draw an unduly exotic picture of Islam. As Andrew March (2012) has objected, in her emphasis on "emotional pain" she even gives an ironically "secularized" version of "Islamic discourse." But her brainy Muslim hermeneutics gives an idea of the depth of the dissent underneath the protest against the Danish cartoons.

As for the alleged incapacity of "secular law" to protect the "religious sensitivities" of Muslims (Mahmood), it should be mentioned that Britain at least came very close to recognizing them. The original version of the 2006 Racial and Religious Hatred Act would have outlawed "to knowingly use words, behaviour or material that is threatening, abusive or insulting with the intention or likely effect that hatred will be stirred up against a group of people targeted because of their religious beliefs" (quoted in Malik 2005, p. 3; emphasis added by CJ). As critics pointed out, this vague formulation, targeting also human expressions that are merely "abusive" or "insulting" (which is always in the eye of the beholder) and whose "likely effect," not necessarily their "intention," is to produce "hatred," might put many a literary production on the Index, in an ironic twist perhaps even Koran or Bible, which include not a few ferocious passages. The precise formulation was taken from an already existing law against racial hatred, which was simply to be extended to the fact of religion. But "race" and "religion" are different matters, critics argued, for one because "religion" consists of propositions that might reasonably be criticized or even ridiculed, in fact have been criticized and ridiculed ever since the European Enlightenment, including their late children Marx and Freud. The Labour government, which was heavily lobbied by 
Muslim organizations to pass the religious extension, naturally denied that it was meant to restrict the freedom of expression or that this was a new blasphemy lawtherefore the nervous insistence that "our proposed law does not protect the belief-it protects people."10 At least one Labour MP suggested otherwise. When the bill was debated in Parliament, he stated: "In the context of Salman Rushdie, the issue was the abusive words that he deliberately used, which were written in phonetic Urdu..." (quoted in Ash 2005). At least for this parliamentarian, the Satanic Verses obviously came within the scope of the bill, and for him this was something to be tested in court. Moreover, in judging expressions not by their intent but their "likely effects," the sheer fact of disorder or violence provoked by them, perhaps even on part of the victim rather than the perpetrator, could be taken as legal ground for prohibition. Overall, this was not far from what the Muslim states' "defamation of religion" campaign had wanted at the international plane. As a critic argued, in words that closely resemble those exchanged in the Hart-Devlin debate, the proposed speech restriction was to "make a moral statement about what is and is not socially acceptable" (Malik 2005, p. 4).

However, the House of Lords, when reviewing the bill, was attentive to the opposition, especially by artists and intellectuals on the political left, who feared for the freedom of expression. They added two important amendments that significantly watered down the scope of the law. In the end, only expressions that were "threatening" came to be prohibited (which was less than "abusive" and "insulting"), and "intention" had to be proved (by dropping the "likely effect" alternative, which had voided the need for proving intention). The 2006 Racial and Religious Hatred Act thus did not amount to the potentially massive restriction of free speech that its earlier version could have been. As Eric Bleich concludes, "( $t$ )he upshot of this battle over public values is a law that forbids very narrow forms of incitement to religious hatred while at the same time reaffirming a deep commitment to freedom of expression within Britain" (Bleich 2011, p. 25).

While free speech laws have generally withstood the Islamic challenge, the latter has nevertheless managed to occupy the moral high ground. This is proved by the remarkable success of the neologism "Islamophobia," the questioning of which has come to be seen an instance of the designated phenomenon itself, and which has become a fixed entry in the public vocabulary (for Britain, where the concept was invented, see Joppke 2009b, p. 456459). Moreover, returning to the Danish Cartoon crisis, not just a former US president, but incumbent Western state leaders like Tony Blair and George Bush attacked the "offensive drawings" (Hansen 2006, p. 3). Tariq Modood (2006, p. 3) referred the fact that in Britain the incensed cartoons were not even allowed to be reprinted to "progress since the Satanic Verses affair," and to his country's "greater understanding ... about anti-Muslim racism." The selfcensorship happened just before the Racial and Religious Hatred Act went into effect, which attests to the irrelevance of the new law with or without amendments - moral self-censorship already did the work that the law was supposed (or not) to do. When a hard-lining, anti-Islamic polemicist in Denmark, leader of his own Free Press Society, narrowly escaped a murder attempt, he was predictably described as “previously shunned by Denmark's

\footnotetext{
10 "(O)ur proposed law does not protect the belief - it protects people," stated Minister Fiona Mactaggart, "It will still be OK to ridicule religion," The Guardian 14 March 2005 (www.theguardian.com/world/2005/mar/ 14/religion.politics) (last accessed 26 June 2014).
} 
intellectual and political elite," and in turn a moderate Danish Muslim leadership condemning the attack was praised for their "calls for tolerance." 11 It may be exaggerated to say that Western elites and media have "surrendered" to radical Islam (Bawer 2010), but sympathy for the Muslim cause has by no means been negligible.

\section{Veiling and equality of sexes}

The equality between men and women, and veiling in particular, has been a second source of protracted dissent and conflict between Western and Islamic actors and viewpoints. Interestingly, here the conflict constellation is the reverse. Whereas with respect to the freedom of speech Muslim actors had demanded moral regulation by law, here the impulse of moralization originates from Western constituencies, and thus unsurprisingly it has often been blessed with more success.

That public morality is pushed in Western states' headscarf restrictions, dubious from a liberal point of view, tends to be obscured by the fact that this morality comes in liberal cloth. All of these restrictions face the problem that fundamental liberties are restricted, most often in the absence of demonstrable harm to a third party - which violates Mills's harm principle. However, not all of these restrictions are equally noxious. In particular, as I shall argue, liberal arguments can be mustered to justify restrictions in public institutions, most importantly the school. By contrast, much more difficult to justify are the recent "burqa laws" in some countries (especially France), which prohibit complete veiling in public places.

Three questions will help to navigate in this vexed terrain, where the badge of female oppression under Islam to some is expression of Islamic feminism to others:

- first, why is there conflict in the first;

- second, why is it stronger in some countries than in others;

- and third, what is the concrete nature and scope of the restriction?

With respect to the first question, about why there is conflict at all, it has been noted that "most cultures have as one of their principal aims the control of women by men" (Moller Okin 1998, p. 667), a fact that seems to be related to the uncertainty of paternity and the importance of female primary parenting for cultural reproduction (ibid.). More concretely, the headscarf conflict is as old as European colonialism, where the forced unveiling of Muslim women for the sake of liberating them was responded with politically loading the veil as a symbol of resisting Western domination. Leila Ahmed bitingly connects the cultural universal with the historical particular: "(T)he Victorian colonial paternalistic establishment appropriated the language of feminism in the service of its assault on the religions and cultures of Other men" (1992, p. 152). On the opposite end, as "the occupier was bent on unveiling Algeria," as Frantz Fanon accused the French colonialists (ibid., p. 164), the veil was set to be a symbol of resistance. This function it retained, or rather recovered, in the Islamic Revival that has seized the Muslim world, along with its Western diaspora, since the 1970s, and has opposed "secularization" and "westernization" tout court (Mahmood 2005, p. 44). Nilüfer Göle observes in her classic study on Islamic veiling among Turkish university

11 “Denmark's Muslims follow a new script," International Herald Tribune 28 February 2013, p. 4. 
students in the 1980s that "(w)ith the act of veiling women perform a political statement against Western modernism" (1996, p. 136).

The rub is that Islamic feminism in general, and the headscarf in particular, underwrites patriarchy, which the West in turn could get rid of in a much bigger way than many a liberal academic is willing to concede. Note, ad hominem, that it is most often women, and tenured faculty at American elite universities at that, who rail against "colonial feminism" (Leila Ahmed 1992, now at Harvard) and against the idea of "white men saving brown women from brown men" (Lila Abu-Lughod 2002, of Columbia University); the list of Western elite women finding no fault with Muslim women's subordination (some mentioned in this article) could be easily prolonged. To stay within the metaphor, amongst themselves "brown men" and "brown women" have no illusion that "equality" is not the usual way to relate to one another. Tariq Ramadan (2009, p. 52), for instance, who is a self-declared Islamic feminist, draws a picture of women that is more one of "complementarity" than of equality with men (e.g., Ramadan 2009, p. 52). The typical reference that women in Islam enjoy "absolute equality before God" (Ramadan 2001, p. 52), while not wrong, is still deceptive because equality before God does not imply the equality of men and women in relationship to one another. In latter respect, women are above all "daughters," "sisters," "wives," or "mothers," says Ramadan (2009, p. 211). Make no mistake: all Abrahamic (sic!) monotheisms are deeply patriarchal, even misogynist. But the female element is more strictly repressed in Islam than in Judaism, where women - not men - transmit religion, and in Christianity, where a woman is even mother of God (see Bellah 1970, ch.8).

The headscarf in particular is intricately tied up with female subordination, whether it is donned for primarily political or religious reasons. For Göle, who stresses the political dimension, headscarf-insistent Turkish university students still "seem to accept the male domination that rests their own invisibility and their confinement to the private sphere" (1996, p. 136). But also if the headscarf is purely religious, expressing nothing but "piety," it is "ineluctably intertwined" with "male superiority" (Mahmood 2005, p. 175). Mahmood further explicates the linkage: "Obedience to one's husband is... an obligation to which every Muslim woman is bound" (p. 178f). "Obedience" and thus inequality is the meaning of the headscarf even if the latter is freely chosen, as is both the case in Göle's (1996) Turkish student movement and in Mahmood's (2005) Egyptian "piety movement." "Choice," of course, is a treacherous (though unavoidable) concept to use in this regard, because for pious Muslim women the headscarf means "both a choice and, importantly, an obligation, a divine prescription incumbent on all Muslim women" (Fernando 2010, p. 24) - the headscarf's simultaneity of being choice and obligation allegedly allows "no discursive space" for it in the secular West (ibid., p. 29). Whatever the headscarf's semiotic intricacies, chosen and obliged, political and religious, its Western critics have not capriciously zeroed in on the inequality of women that seems inevitably connected with it.

However, is this inequality sufficient ground to legally restrict the headscarf? Toronto jurist Mohammed Fadel (2012) has plausibly pointed out that a position like that of influential Muslim cleric Yusuf al-Qaradawi, which endorses equal rights for women in the political sphere but subordinates wives to husbands in the family sphere, is compatible with Rawls's "political liberalism" (1993). This is because, according to Rawls, "equal citizenship for women" can go along with inequality in the family thatqua being considered, however implausibly, an "association," not unlike churches, universities, or business firms - is only partially subjected to the principle of justice 
(see Rawls 1999, pp. 156-164; for a compelling feminist critique, see Moller Okin 2005). From a Rawlsian perspective, the liberal critique of the inequality between men and women in Islam is overshooting because it demands "equality" even where the state has or should have no reach, the private sphere of individuals. And if equality is ordered by law, as in the headscarf laws of some European countries, it goes along with the legal enforcement of morality, at best in the form of "legal paternalism" (Feinberg 1988 , p. xix), which in the case of the Islamic quest for the protection of religion has exactly been rejected by Western actors and institutions.

To be precise, a restriction of the headscarf for the sake of enforcing equality between men and woman is at the intersection of "legal paternalism" and "legal moralism," as defined by Feinberg (1988). For Feinberg, "legal paternalism" is to prevent harm to the same person who is acting. Such "harm" has to be objectively defined by others and its prevention by definition violates the autonomy of the actor. Feinberg therefore classifies legal paternalism, together with "legal moralism" (that is to prevent "inherently immoral" conduct that does not harm anyone), as "non-liberal" restriction of freedom. Prohibiting the (freely chosen) headscarf for its violation of the equality norm is both legally paternalist and legally moralist, because "harm" is inflicted by the headscarf woman against herself, but only in light of an idealized moral picture of how women "ought to" relate to men, as "equal."

Having rendered plausible why there has been conflict about Islamic veiling in the first it, secondly, needs to be answered why it is stronger in some countries than in others. Not by accident, the mother of all headscarf controversies is France, whose "Republican" state has pursued the Western world's most ambitious ethical society-building project for over 200 years now. All (continental) European states, which had to compete over the centuries with the Catholic Church for supremacy, are to a degree soul- and identity-makers, taking over this function from the church (see Whitman 2008) - much in contrast to the "AngloAmerican tradition," where "medieval Church functions have ... never been assumed by the state" (ibid., p. 91). Grossly simplifying, therefore no headscarf controversy in the United States, and very little of it in Britain. Liberalism in the Anglo-American tradition connotes pluralism and toleration, with civil society dominating the state (enduringly instructive are Badie and Birnbaum 1983, ch.7). By contrast, liberalism in France connotes the production of autonomous and equal citizens by the "Republican" state that leaves little space for civil society (ibid., ch.8). From here stems an obsession with "integration" that long predates its contemporary association with immigrant integration. Dominique Schnapper (1994, p. 73f), an authentically Republican sociologist, tellingly finds that integration requires a "transcendence" of one's prior allegiances and origin features. As the word conveys, "transcendence" is para-religious, seeking to "imprint the republic in hearts and souls" (Jules Michelet quoted in Schnapper 2006, p. 166). Accordingly, laïcité is not merely the French word for liberal neutrality but stands for "the essential fact that the social tie is no longer religious but national and thus political" (1994, p. 74). This formulation betrays that the religious and the national are not indifferent but substitutive, with the generic possibility of conflict. Islam today is being assigned the opposite role that in the nineteenth and early twentieth century was filled by the Catholic Church that formidably resisted the substitution of "religious" by "national."12

\footnotetext{
${ }^{12}$ The diagnosis of the French headscarf controversy in terms of "racism" toward Islam and Muslims misses this essential point (Scott 2007).
} 
But, thirdly, headscarf restrictions need to be calibrated according to where and when they apply, some restrictions being more odious from a liberal point of view than others. In this respect, there has been significant evolution. In Round One of the European headscarf struggles, the issue was institution-specific restrictions of the ordinary headscarf (covering hair but not the face), especially in schools, public offices, or the workplace. Interestingly, courts have strongly protected the headscarf at the private workplace, ${ }^{13}$ even when "appearance" is not unrelated to work performance (as, for instance, in the cosmetics section of a high-end department store). However, the real site of conflict at this stage was public education, where religious dress on the part of civil servants, not without good reason, has been taken to conflict with the liberal state mandate to be "neutral" on religion. Only France went further, legislating against the headscarf of pupils in 2004. This law, meant to beef up laïcité as central plank of Republican identity, entailed a novel definition of state neutrality, even under a traditionally expansive French laïcité. It now obliges not only the "providers" but also the "users" of state services, in this case schoolchildren. However, as the traditional practice of school uniforms in many countries (including liberal Britain) attests, even this more expansive restriction may be liberally justified by protecting non-headscarfwearing girls from peer pressure, and by keeping away disturbing group interference from public education, much as other public institutions (like courts) or the workplace have also required some moderation for fulfilling their specific functions.

Round Two of the European headscarf struggles, instigated by the increasing electoral strength of the far right across European states, is altogether different. Only now we enter the true realm of "legal moralism" (Feinberg 1988), where a "non-grievance evil," unconnected to any personal harm, but also unconnected to any disturbance of public institutions, is to be gunned down by state law. In this stage the veil proper ("burka" or "niqab," covering all or most of the face) is targeted for restriction, in public space at large. Examples are the French and Belgian "burka" laws passed in 2010 and 2011, respectively. This amounts to the perhaps most drastic liberty restriction imaginable in the contemporary liberal state, what to wear in the streets. How can it be justified?

To make this liberty restriction compatible with European human rights law, it was necessary to argue, as the French government did, that the burqa is not really a religious symbol but a sign of political extremism. Nevertheless, the legal-constitutional hurdles to pass a general burqa prohibition were still dauntingly high. ${ }^{14}$ Interestingly, laïcité, which had justified the 2004 anti-headscarf law for public schools, was not a possible recourse. This is because laïcité is a principle to regulate the relationship between the state and religion, not private people in public places. Emphasis therefore shifted to "human dignity," which could be taken to be violated by the veil, this "sign of subjugation (and) of debasement," as French President Sarkozy called it in his opening salve of the anti-burqa campaign. ${ }^{15}$ A dignity approach squared with the focus on

\footnotetext{
13 This has been the case even in France, at least until the most recent "Baby-Loup" decision of the Court de Cassation (France's highest court for civil and penal law) that surprisingly upheld the firing of a veiled teacher in a private crèche near Paris (called "Baby-Loup"). The court thus overruled its own lower chamber's prior indictment of this firing as violation of the teacher's religious liberty rights. The June 2014 decision is an important step for imposing laïcité also in the private sector, from which it had been previously absent. Court de Cassation, Arrêt du 24 Juin 2014 ("Baby-Loup"), no. 612, Assemblée plenière.

${ }^{14}$ See the detailed discussion in Joppke and Torpey (2013, ch.2).

${ }^{15}$ Libération, 22 June 2009, www.liberation.fr/.
} 
women's equality that had undergirded the French (and European) conflict with Islam all along.

However, the visibly astounded French lawmakers had to learn from constitutional jurists that, as a legal principle, "dignity" is a subjective concept that can be violated only by a third party but not by the actor against herself. Legally understood, dignity is tantamount to human freedom. Considering that the burqa, as the evidence suggests, is usually "chosen" by the woman and not imposed on her by men, the burqa becomes, weirdly, an expression rather than negation of the woman's dignity, contrary to what burqa foes argued. As laïcité and "dignity" were thus off the table as justification for a burqa law, rescue was sought in a third legal principle, "public order." According to it, the burqa might be construed as a security threat. However, from the point of view of "security," a public dress restriction had to be tailored to specific times and places and could not be general, because this would be a disproportionately drastic restriction of liberty.

At first, these constitutional obstacles seemed to bury the prospect of a general antiburqa law in France. But there was unflinching political support for such a law on part of a Gaullist center-right government that was intent on creating headwinds for the far right. Accordingly, all that was required was a little legal engineering. Some lawyers suddenly turned their attention to the fact that "public order" contained not only a "security" but also a "morality" dimension — never mind that this part of public law had been dwindling over the past half century, due to some of the same concerns that Hart (1963) had prominently expressed in his debate with Justice Devlin. However, as the argument now went, if nudity in the street is prohibited, why not outlaw its exact opposite, complete veiling? This "non-material" dimension of public order had never been adequately "legally formalized," observed the Conseil d'Etat (2010) in its negative opinion on the possibility of a total burqa prohibition. But here was the legal bridge that could be built. The Conseil d'Etat itself provided the formula: "Public order rests on the minimal fundament of reciprocity and the essential guarantees of social life" (p. 26). "The Republic is lived with unconcealed face," the Justice Minister would articulate the underlying idea more colloquially, when presenting the burqa bill to the National Assembly. ${ }^{16}$ The Republican sociologist and former member of the Conseil Constitutionnel (France's highest court reviewing new laws in parliament), Dominique Schnapper, expressed the law's controlling idea almost comically: "France is the country where everyone says 'Bonjour"' (quoted in Bowen 2011, p. 337). The French burqa law is "affirmation of the right of equal belonging to the social body," as the Conseil d'Etat (2010, p27) formulated the prospect of a veiling law, not exactly in perfect clarity. A parliamentary report put it this way:

In the Republic, reciprocity and exchange are two essential notions and the French society is deeply marked by the notion of 'civility'. Behind this term, there is the idea that, in a society, customs have to be policed and rules should be followed as to permit a civilized exchange between individuals. The concealing of the face is perceived as undermining our social code represented by a set of norms which are consensual" (quoted in Weil 2014, p. 195f, fn.4; emphasis added by CJ).

\footnotetext{
${ }^{16}$ Assemblée Nationale, Compte rendu no. 75, Commission des lois constitutionnelles, de la législation et de l'administration générale de la République, 6 July 2010, p. 2.
} 
To repeat the key phrase in this remarkable statement: "customs have to be policed." This was the essence of it. While not devoid of a liberal-universalist clothing, the French burqa law is "a defense of the particular French way of life" (Slavoy Zizek, quoted in Elver 2012, p. 197). The Clapham omnibus riders have had an unexpected return. $^{17}$

\section{Conclusion}

The culprits in the rejuvenation of the idea to enforce morality by law are evidently on both sides: Western host society no less than Islamic constituencies. From a liberal point of view, these efforts stand to be rejected with the same reference to Mill's Harm Principle that H.L.A. Hart had convincingly brought against Lord Devlin some 60 years ago: "The only purpose for which power can be rightfully exercised over any member of a civilized community, against his will, is to prevent harm to others. His own good, either physical or moral, is not a sufficient warrant" (Mill 1982 [1859], p. 68). However difficult or even impossible it may be to live up to this principle, which obliges the state to be neutral on questions of morality and the good life, this is the quintessential liberal state principle that the challenge of Islam integration is putting to the test.

Having said this, we need to differentiate further with respect to the contents and structural positioning of the two morality campaigns, the one originating from and the other targeting Islam. The Islamic "restrict speech" campaign, as it has been conducted by or on behalf of a minority group, is notionally not within the ambit of the "enforcement of morals" as endorsed by Lord Devlin, at least to the degree that our emphasis was Islam in a non-Islamic majority society. Note that Devlin gave pride of place only to the "morality" of majority society (1963, p. 10), not to that claimed by minorities. In turn, if Devlin would have his way with respect to the standing of Islam and Muslims in the West, it would amount to a regression of epic proportions, a return to the Dark Ages before multiculturalism. The Clapham omnibus riders would just rid themselves of the spoilers (or, more moderately, ignore any of their claims). Moreover, precisely because it was conducted by a minority, the restrict-speech campaign was couched in the idiom of rights, the rights of religious freedom, non-defamation, and nondiscrimination that were seen infringed by "offensive" speech. This signals an adjustment on the part of Islamic actors to an individual-centered, liberal rights framework; even though this framework may be foreign to Islam (this paradox is briefly touched on in Joppke 2013b, p. 431f; more detailed in Joppke 2015, ch. 4). Devlin's position boils down to a factual, quite literally unreasoned "this is how things are done around here" that, most of the time, not even majority society actors have dared to take in their headscarf oppositions - with the one exception of the French burqa law, whose official "reciprocity" justification, however, is still couched as abstract universal.

In fact, a variety of contra-headscarf arguments have been brought forward that are plainly outside the "public morality" discourse intoned by Lord Devlin. The German

\footnotetext{
${ }^{17}$ In early July 2014, the European Court of Human Rights (ECtHR) validated the French burqa law, arguing that the "preservation of the conditions of "living together"" was a legitimate state concern that in this case trumped religious liberty rights (ECtHR, Case of S.A.S. v. France, 1 July 2014, at par. 157).
} 
headscarf laws targeting public school teachers have been for the sake of the "neutrality" of the state, which was seen impaired if civil servants display partiality through religious dress (Joppke 2009a, ch.3; also 2007b, pp. 326-328). ${ }^{18}$ The French 2004 headscarf law targeting high school students, while mainly defended in the name of laicité as core value of the French Republic (and thus a "public morality" defense à la Devlin), has also included an element of individual rights protection, because laïcité can also be seen as religious liberty protection. For some "liberal" headscarf opponents (like Weil 2004), banlieue girls were to be protected from traditionalist male pressure. And the Belgian burka law of 2011, while similar in its content to the French law of 2010, has been presented primarily as a non-normative "public safety" measure, and only secondarily as a public morality defense that had been the gist of the French restriction. ${ }^{19}$ Importantly, and proving wrong Devlin's moral populism, not the say-so of the Clapham omnibus user but reasoning within a liberal framework has accompanied most European headscarf restrictions, including those okayed by British courts (see the overview in Joppke 2009a).

But is it perhaps misguided from the start to apply the terms of the Hart-Devlin debate to the issue in question, Islam integration? Let me briefly discuss, and rebut, three ways of launching this objection. The first would be to consider the private question of sexual morals, the subject of the Hart-Devlin debate, as different in kind from the public question of "shared values" that drives the agenda of the Islam debate (see note 4). However, as I suggested, no clear line can be drawn between private and public in matters of morality, which is an inherently social (and thus, to a degree, public) thing. ${ }^{20}$ In one plausible interpretation, "eros" (and not "demos"), that is, different views on sexual rather than on political matters, is what really divides "Islamic" from "Western" viewpoints (see Norris and Inglehart 2002; see also my discussion in Joppke 2014a). At least we can say that removing "sex" from the Islam debate would leave one with a good deal less to argue about, even if the explicit matter is free speech. ${ }^{21}$

A second possible objection is more against John Stuart Mill's Harm Principle that Hart, compellingly in my judgment, brought against Devlin's moralism as the quintessential liberal state principle. Eugene Rostow (1960), defending Devlin against Hart, retorted to the Harm Principle: "Men often say that one cannot legislate morality. I should say that we legislate hardly anything else" (p. 197). According to a Rostowian, capacious definition of morality, "what is an old-age pension scheme but an enforcement

\footnotetext{
${ }_{18}$ Although within the ambit of Devlin's "public morality" defense are the provisions in the headscarf laws of some (catholic-conservative) German Länder that exempt from the restriction Catholic nun teachers, on the grounds that the state can be partial for "Christian-Occidental" majority culture.

${ }^{19}$ See ECtHR, S.A.S. v. France, at par. 42, which summarizes the Belgian burqa law and its subsequent validation by the Belgian Constitutional Court.

${ }^{20}$ Also note that Jonathan Sacks (2007, p38-41) has taken (and critiqued) the recommendations of the Wolfenden Committee, as well as Hart's defense of them, as epitomizing a general shift toward homeless "proceduralism" in the liberal state, which presupposes that not just "private" but "public" morality has been the issue in this debate. Of course, Sacks (and this author) might still be plainly wrong. Therefore an adequate defense hinges on the impossibility of a purely private morality, as suggested in these pages.

${ }^{21}$ What incensed Muslims about the Satanic Verses was not least sexual libertinism attributed to the Prophet (see Parekh 1990, pp. 697-698). And one of the Danish cartoons shows a heavenly gatekeeper (dressed like Mohammad) trying to keep back armed martyrs with the words "Stop stop we ran out of virgins!" However, in a Christian context also contemporary "blasphemy" is most often couched in sexual imagery. See the famous European Court of Human Rights 1994 decision Otto-Preminger Institut v. Austria (discussed in Joppke 2013a).
} 
of morality?" (ibid.). Rogers Smith similarly argued that "all law is about enforcing morality," so that the question could not be to cleanse the law of morals but "which morality to enforce." 22

But following this advice would greatly reduce our possibilities to classify types of law and public policy. In a good attempt at policy classification, Christoph Knill lists abortion, euthanasia, gun control, same-sex unions, pornography, prostitution, drugs, and gambling as subjects of a single class of "morality policies," which he defines as "shaped by conflicts over first principles" (2013, p. 309). Knill further distinguishes within this class between "life and death," "sexual behavior," "addictive behavior," and "freedom v. order" related policies (the latter subtype including religious issues), each with its own specific dynamics and actor constellations (ibid.). Next to typical policy contents, as laid out by Knill, one has to add a second criterion that distinguishes morality policies from other policies: the "absence of a 'victim' or damage to specific and direct interest of others," as Gusfield put it in one of the few sociological accounts of "legislating morals" (1968, p. 54). ${ }^{23}$

However, even if morality is understood in a suitably narrow sense, as is the premise of this article, it is true that the exceptions to Mill's harm principle are legion. Devlin provocatively said about England in the early 1960s: "Mill's doctrine has existed for over a century and no one has ever attempted to put it into practice" (Devlin 1965, p.125). While this is exaggerated, "a great deal of law that is inconsistent with the doctrine" (p.127) did exist at Devlin's time and continues to exist today. Obvious examples are extant laws on bigamy, cruelty to animals, abortion, incest, obscenity, bestiality, homosexuality, and pimping (listing only those laws mentioned by Devlin himself, ibid.). However, one must respond that the number of such laws has either diminished (as with respect to "homosexuality," no longer on the list), ${ }^{24}$ or that their rationale has been refashioned from religioustraditionalist into individual rights terms (though most often inevitably paternalist). Thus refashioned, they protect the interests and integrity of vulnerable categories of people or organisms (women, children, animals in six of the eight morality laws cited by Devlin), but also of human beings and citizens in general (as in the case of "obscenity," that tends to be rejected today for being "offensive"). If there are still laws on the books, like those on bigamy, that only strenuously can be folded into a liberal mold, one may still respond: this only shows that "present law is not based on exclusively liberal principles, not that it ought not to be based solely on such principles" (Feinberg 1988, p. 165).

\footnotetext{
${ }^{22}$ Rogers Smith (University of Pennsylvania), in a response to my talk in Jerusalem in March 2013.

${ }^{23}$ An interesting alternative is to identify "morality policies" not so much by their content as by the approach taken in them, "radical" v. "mainstream." Ted Lowi suggested this (1988). He first grouped what I call (with others) "morality policy" as part of a broader category of behavior-related "regulatory policy." He then subdivided the latter into a "radical" approach that considers wrongdoing "sin" and seeks to eradicate it as a matter of principle, and a "mainstream" approach, for which the wrongdoing is merely "error" that stands not to be "eliminate(d)" but "reduce(d)" for its negative consequences (p. xviii). The advantage of this approach is that it can reckon with the continued existence of morality policies in the liberal state, which may be conducted in a liberal ("mainstream") or illiberal ("radical") way. For our purposes important is that also Lowi's proposal acknowledges that not any policy is morality policy.

${ }^{24}$ With respect to homosexuality, the last frontier today is the acknowledgment of gay marriage, which is rapidly advancing. See the global overview in The Economist ("Gay marriage: to have and to hold"), 17 November 2012, 58-59.
} 
But perhaps, to flag in closing a third possible objection to the normative-cumempirical diction of this article, it is misguided to apply an "Anglo-American" view of the law, as articulated by Hart (1963) and, in his wake, Feinberg (1988), to continental European states that have much less qualms to legislate public order and morality, even today? ${ }^{25}$ However, this would amount to saying that continental European are not liberal states, and thus not bound by the norms laid out not only by Hart and Feinberg but by more other liberal legal theorists and political philosophers than we can count, from Dworkin to Rawls, even Habermas (to name only those mentioned in this article). Such a radical provincializing of liberalism would not convince many, to put it mildly.

Finally, the question cannot be avoided of whether there is anything intrinsic to "Islam" that makes this religion and the people under its sway particularly difficult to integrate into liberal societies. The fact that freedom-restricting moralizations have originated equally from Islamic and Western host-society quarters suggests caution in this respect — not to mention that the criminalization of homosexuality in Devlin's time obviously had Christian roots. Indeed, as long as Christian ethics shaped the law and politics of Western societies, which was the case well into the 1960s, the implications were starkly liberty-stifling. Before the 1960s, Europe and America alike were "Christian countries" in a coercive legal way, with laws that regulated morality on the basis of explicitly Christian principles, prohibiting blasphemy, homosexuality, divorce, abortion, contraception, commerce on Sundays, gambling, even drinking. When presenting an omnibus bill that lifted a good number of these prohibitions in 1967, Canadian Premier Minister Pierre Trudeau explained that "it would be a mistake for us to try to legislate into this society concepts which belong to a theological or sacred order," and - more bluntly - he vowed to "get the state out of the nation's bedrooms" (quoted in McLeod 2010, pp. 217 and 216, respectively).

Let me approach the prickly "Islam" issue in an indirect way, ${ }^{26}$ by exposing some inconsistencies that result from defining it away as a "problem," which is very much the academic mainstay today, out of a panicky fear of "Orientalizing" and "essentializing" the religion and its people. In an insightful analysis of the "Park 51" opposition, that is, the campaign to prevent the building of a mosque near New York's "Ground Zero" (site of the terrorist attacks in 2001), the young French political theorist Marzouki (2011) has shown that the mosque opponents took a stance that was perfectly symmetric to that adopted by aggrieved Muslims in the Danish Cartoon Controversy: a sense of "moral offense" bickering for "recognition" was played out against a liberal law that protected the "rights" of the other side (free speech rights on part of the Danish cartoonists, and property and religious liberty rights that now protected the New York mosque builders). Interestingly, knowing that there was no legal-constitutional redress for their cause, "Park 51" opponents explicitly evoked the symmetrically inverted constellations in the Danish and New York controversies, which saw Muslims miraculously transformed from victims into beneficiaries of a legalism that entailed moral offense to the other side: "We have to respect Muslims.... But where is the respect for us? There are many other places where they can build their mosque. In the Muslim world, symbols are taken very serious. Just take the caricatures (of the Prophet Mohammad). What have (Muslims)

\footnotetext{
25 This objection has been raised by an anonymous reviewer of this article.

${ }^{26}$ For more direct statements about frictions between "Islam" and the principles of liberal societies, see Joppke (2014b) and Joppke (2015, ch.4); also Joppke and Torpey (2013, pp. 145-153).
} 
done in response? They took their anger to the street.... One sees how much importance they accord to symbols" (Marzouki 2011, p. 852).

From the "symmetrically opposed" stances taken by Muslims and non-Muslims in the Danish Cartoon and Park 51 controversies, Mazourki (2011, p. 852) intriguingly concludes that these stances are to be entirely understood by their structural position in a "language game," without any grounding in an "extralinguistic reference" or "culture": "The dialogical inversion of the argument from moral offense and its appropriation by a public inscribed in the liberal-Protestant tradition, while American Muslims have taken recourse to a secularized register of constitutional rights, shows that the argument from offense is not tied up with a particular tradition or subjectivity" (p. 859).

However, is it really true that "everything is words," as Marzouki (2011, p. 865). claims with Balzac? Marzouki also notes that Park 51 opponents were beholden to a "liberal conception of harm," as the incensed mosque was not objected for the sake of a "moral doctrine," "blasphemy against a God," or a "holy tradition," but in secular memory of the victims of the terrorist attack of 11 September 2001 (p. 861). Moreover, no frontal attack on the limitations of "secular law" was made by Park 51 opponents, while such lament was loud and clear on the part of the Danish Cartoon opponents (e.g., Mahmood 2009). A bit of cool structuralism, for which there is no intrinsic meaning to signs outside their relations, is a useful antidote to the hotter "clash of civilizations" rhetoric that vitiates the debate on Islam in the West. But too much of it would equally distort the fact that there are substantive, not only rhetorical issues at stake.

Islam is a problem for liberal societies. This was revealed in this article through some of Islam's illiberal claims but also, indirectly, through the illiberal responses that proliferate today in the name of liberalism. This is not to hold the victim responsible for the aggression. But the aggression, after all, is triggered by the affront to the core values of liberalism that is difficult not to be read into some of the extreme forms of Islamic dress. There is ample material in this article to suggest that Islam and liberalism are in tension with one another and that any claim to the contrary would carry the burden of proof.

Acknowledgments The idea for this article was first presented at the conference "Immigration and the Future of the Nation-State," held at the Israel Democracy Institute in Jerusalem, 17-18 March 2013. The first draft was read at the Symposium on Law, Politics, and Religion at the School of Law, Edinburgh University, 9 September 2013, and at the Juan March Institute, Madrid, on 14 October 2013. I am grateful to two anonymous reviewers of this journal, and particularly to Rogers Brubaker, in his capacity as a Theory and Society Senior Editor, who pushed me to two rounds of revision that made this article grow (also in length). Now that the final result is published, I regret that it means that I need to write another paper to "run around" with.

\section{References}

Abu-Lughod, L. (2002). Do Muslim women really need saving? American Anthropologist, 104(3), 783-90. Ahmed, L. (1992). Women and gender in Islam. New Haven: Yale University Press.

Ali Khan, L. (2007). Combating defamation of religions. The American Muslim (available at http://ssrn.com/ abstract=954403).

Allawi, A. A. (2009). The crisis of Islamic civilization. New Haven: Yale University Press. 
Asad, T. (2012). Freedom of speech and religious limitations. In C. Calhoun, M. Juergensmeyer, \& J. VanAntwerpen (Eds.), Rethinking secularism. New York: Oxford University Press.

Ash, T. G. (2005). Stop this folly now. The Guardian, 17 February 2005 (www.theguardian.com/politics/2005/ feb/17/religion.uk) (last accessed 26 June 2014).

Badie, B., \& Birnbaum, P. (1983). The sociology of the state. Chicago: University of Chicago Press.

Bassham, G. (2012). Legislating morality: scoring the Hart-Devlin debate after fifty years. Ratio Juris, 25(2), $117-132$.

Bawer, B. (2010). Surrender: Appeasing Islam, Sacrificing Freedom. New York, N.Y.: Anchor Books.

Becket Fund for Religious Liberty. (2008). 'Defamation of religions': submission to OSCE human dimensional meeting 2008. Washington: Becket Fund.

Bellah, R. N. (1970). Beyond belief. Berkeley: University of California Press.

Bleich, E. (2011). The freedom to be racist. New York: Oxford University Press.

Bowen, J. (2006). Why the French don't like headscarves. Princeton: Princeton University Press.

Bowen, J. (2011). How the French State justifies controlling Muslim bodies. Social Research, 78(2), 325-348.

Conseil d'Etat (2010). Etude relative aux possibilités juridiques d'intervention du port du voile intégral. 30 March (www.conseil-etat.fr).

Dassetto, F., Ferrari, S., \& Maréchal, B. (2007). Islam in the European Union. Brussels: European Parliament.

Devlin, P. (1965). The enforcement of morals. Oxford: Oxford University Press.

Durkheim, E. (1984). The division of labor in society. New York: Free Press. 1893.

Dworkin, R. (1977). Liberty and moralism. In R. Dworkin (Ed.), Taking rights seriously. London: Duckworth.

ECLJ (European Center for Law and Justice). (2008). 'Combatting defamation of religions': submission to the UN office of the high commissioner of human rights. Strasbourg: ECLJ.

Elver, H. (2012). The headscarf controversy. New York: Oxford University Press.

Fadel, M. (2012). Muslim reformists, female citizenship and the public accommodation of Islam in liberal democracy. Religion and Politics, 5(1), 2-35.

Feinberg, J. (1985). Offense to others: the liberal limits of the criminal law (vol. 2). New York: Oxford University Press.

Feinberg, J. (1988). Harmless wrongdoing: the liberal limits of the criminal law (vol. 4). New York: Oxford University Press.

Fernando, M. L. (2010). Reconfiguring freedom: Muslim Piety and the limits of secular law and public discourse in France. American Ethnologist, 37(1), 19-35.

Frank, D. J., \& McEneaney, E. H. (1999). The individualization of society and the liberalization of state policies on same-sex sexual relations, 1984-1995. Social Forces, 77(3), 911-944.

Frank, D. J., Camp, B. J., \& Boutcher, S. A. (2010). Worldwide trends in the criminal regulation of sex, 1945 to 2005. American Sociological Review, 75(6), 867-893.

Göle, N. (1996). The forbidden modern. Ann Arbor: University of Michigan Press.

Gusfield, J. (1968). On legislating morals: the symbolic process of designating deviance. California Law Review, 56(1), 54-73.

Hafez, K. (2013). Liberty, equality and intolerance: Islam in Liberal Europe. Unpublished manuscript.

Hansen, R. (2006). The Danish cartoon controversy: a defense of liberal freedom. European Studies Association, 19(2), 1-6.

Hart, H. L. A. (1959). Immorality and treason. The Listener. 30 July, 162-163.

Hart, H. L. A. (1963). Law, liberty and morality. Oxford: Oxford University Press.

Hart, H. L. A. (1967). Social solidarity and the enforcement of morality. University of Chicago Law Review, $35(1), 1-13$.

Jones, P. (1980). Blasphemy, offensiveness and law. British Journal of Political Science, 10(2), 129-148.

Jones, P. (1990). Respecting beliefs and rebuking Rushdie. British Journal of Political Science, 20, 415-437.

Joppke, C. (2007a). Beyond national models: civic integration policies for immigrants in Western Europe. West European Politics, 30(1), 1-22.

Joppke, C. (2007b). State neutrality and Islamic headscarf laws in France and Germany. Theory and Society, $36,313-342$.

Joppke, C. (2009a). Veil: mirror of identity. Cambridge: Polity.

Joppke, C. (2009b). Limits of integration policy: Britain and her Muslims. Journal of Ethnic and Migration Studies, 35(3), 453-472.

Joppke, C. (2013a). Double standards? Veils and crucifixes in the European legal order. European Journal of Sociology, 54(1), 97-123.

Joppke, C. (2013b). Islam in Europa: Integration durch Recht und ihre Grenzen. Kölner Zeitschrift für Soziologie und Sozialpsychologie 65 (special issue on Religion and Society), 409-435. 
Joppke, C. (2014a). Islam and Europe: Victimists, alarmists, and integration by law. West European Politics (special issue on "Europe in Crisis").

Joppke, C. (2014b). The retreat is real-but what is the alternative? multiculturalism, muscular liberalism, and Islam. Constellations, 21(2), 286-295.

Joppke, C. (2015). The secular state under siege: religion and politics in Europe and America. Cambridge: Polity. Joppke, C., \& Torpey, J. (2013). Legal integration of Islam. Cambridge: Harvard University Press.

Klausen, J. (2009). The cartoons that shook the world. New Haven: Yale University Press.

Knill, C. (2013). The study of morality policy: analytical implications from a public policy perspective. Journal of European Public Policy, 20(3), 309-317.

Laborde, C. (2011). The Danish cartoon controversy and the challenges of multicultural politics. Perspectives on Politics, 9(3), 603-605.

Lowi, T. J. (1988). New dimensions in policy and politics. In R. Tatalovich \& B. W. Daynes (Eds.), Social regulatory policy: Moral controversies in American politics. Boulder: Westview Press.

Mahmood, S. (2005). The politics of piety. Berkeley: University of California Press.

Mahmood, S. (2007). Response to Robert Post (typescript, in author's possession).

Mahmood, S. (2009). Religious reason and secular affect: an incommensurable divide? Critical Inquiry, 35, 836-862.

Malik, K. (2005). Islamophobia myth. Prospect Magazine, 10 February (archive.frontpagemag.com/Printable. aspx?ArtId=9835) (last accessed 26 June 2014).

Mann, M. (1970). The social cohesion of liberal democracy. American Sociological Review, 35(3), 423-439.

March, A. (2012). Speech and the sacred: does the defense of free speech rest on a mistake about religion? Political Theory, 40(3), 319-346.

Marzouki, N. (2011). Offense morale contre liberté religieuse. Revue française de science politique, 61(5), $839-865$.

McLeod, H. (2010). The Religious Crisis of the 1960s. Oxford: Oxford University Press.

Mill, J. S. 1982 (1859). On liberty. London: Penguin.

Modood, T. (2006). The liberal dilemma: Integration or vilification? www.openDemocracy.net.

Moller Okin, S. (1998). Feminism and multiculturalism: some tensions. Ethics, 108(4), 661-684.

Moller Okin, S. (2005). 'Forty acres and a mule' for women: Rawls and feminism. Politics, Philosophy and Economics, 4(2), 233-248.

Norris, P., \& Inglehart, R. (2002). Islam and the West: Testing the 'Clash of Civilizations' Thesis. Working Paper, John F. Kennedy School of Government, Harvard University.

Parekh, B. (1990). The Rushdie affair: research agenda for political philosophy. Political Studies, 38, 695-709.

Post, R. (1988). Cultural heterogeneity and law: pornography, blasphemy, and the first amendment. California Law Review, 76, 297-335.

Post, R. (2007). Religion and freedom of speech. Constellations, 14(1), 72-90.

Ramadan, T. (2001). Islam, the West and the challenges of modernity. Leicester: Islamic Foundation.

Ramadan, T. (2009). Radical reform. Oxford: Oxford University Press.

Rawls, J. (1993). Political liberalism. New York: Columbia University Press.

Rawls, J. (1999). The idea of public reason revisited. In J. Rawls, The law of peoples. Cambridge: Harvard University Press.

Rostow, E. (1960). The enforcement of morals. The Cambridge Law Journal, 18, 174-198.

Sacks, J. (2007). The home we build together. London: Continuum.

Sandel, M. J. (1998). Religious liberty: freedom of choice or freedom of conscience. In R. Bhargava (Ed.), Secularism and its critics. New Delhi: Oxford University Press.

Schnapper, D. (1994). La communauté des citoyens. Paris: Gallimard.

Schnapper, D. (2006). Providential democracy. New Brunswick: Transaction Publishers.

Scott, J. W. (2007). The politics of the veil. Princeton: Princeton University Press.

Starr, P. (2007). Freedom's power: the true force of liberalism. New York: Basic Books.

UN General Assembly (2008). Combating defamation of religions. Resolution 62/154, adopted on 18 December 2007, New York.

Wallace Goodman, S. (2012). Fortifying citizenship. World Politics, 64(4), 659-698.

Weil, P. (2004). Lifting the veil of ignorance. Progressive Politics, vol.3, 1 March, non-paginated.

Weil, P. (2014). Headscarf versus burqa: two french bans with different meanings. In S. Mancini \& M. Rosenfeld (Eds.), Constitutional secularism in an age of religious revival. New York: Oxford University Press.

Whitman, J. Q. (2000). Enforcing civility and respect: three societies. Yale Law Journal, 109(6), 1279-1398. Whitman, J. Q. (2008). Separating church and state: the Atlantic divide. Historical Reflections, 34(3), 86-104. Wolfenden, S. J. (1957). Report of the committee on homosexual offences and prostitution. Home Office, London: Her Majesty's Stationery Office.

Wollheim, R. (1959). Crime, sin, and Mr. Justice Devlin. Encounter, 3440. 
Christian Joppke holds the Chair in General Sociology at the University of Bern, Switzerland. He is also a Recurrent Visiting Professor in the Nationalism Studies Program at Central European University, Budapest, and Honorary Professor in the Department of Political Science and Government, University of Aarhus, Denmark. He received his Ph.D. in Sociology from the University of California, Berkeley in 1989. His recent books are The Secular State Under Siege: Religion and Politics in Europe and America (Cambridge: Polity 2015), Legal Integration of Islam: A Transatlantic Comparison (with John Torpey) (Cambridge, MA: Harvard University Press 2013), Citizenship and Immigration (Cambridge: Polity 2010), and Veil: Mirror of Identity (Cambridge: Polity 2009). He is currently writing a book entitled Is Multiculturalism Dead? Crisis and Persistence in the Constitutional State (to be published by Polity). 